\title{
表面処理によって生じた残留応力のステンレス鋼の疲労強度に及ぼす影響 \\ Effect of Residual Stress Induced by Surface Treatment on Fatigue Strength of Stainless steel
}

\author{
○学 高桑 脩 (東北大 [院]） 正 祖山均（東北大）
}

Osamu TAKAKUWA, Tohoku University, Aramaki aza aoba 6-6-01, Aoba-ku, Sendai, Miyagi Hitoshi SOYAMA, Tohoku University

Key Words : Residual Stress, Fatigue, Surface Treatment, X-ray Diffraction, Two-dimensional Method

1. 緒言

残留応力は機械加工や熱処理, 溶接などによって発生し, 工業的用途に使われる様々な機械部品, 構造物に存在して いる. 表面近傍の残留応力は疲労強度や応力腐食割れに関 わっており,材料の機械的特性に大きな影響を与えている ことが知られている.したがって, 残留応力を正確に計測 することは材料の評価を行う上で非常に重要なことである.

残留応力の計測では，一般的に X 線回折法が多く用い られている，X線回折法には，主に，従来から利用されて いる 0 または 1 次元 PSPC を用いた $\sin ^{2} \psi$ 法(1) と, 近年利 用され始めた2次元 PSPC を用いた2D 法(2)がある。

$\mathrm{X}$ 線回折法の一般的な測定方法では X 線の侵入媣さに より，表面からおよそ $10 \mu \mathrm{m}$ の深さまでの平均的な残留 応力を計測しているが, 機械加工や表面処理を施すことに より，表面から数 $\mu \mathrm{m}$ の極表面層において态力特異場が 存在している. 近年, 極表面層の残留応力はシンクロトロ ン放射光を用いて計測されている(3). しかし, 通常のX 線 を用いた計測方法でも，前述した 2D 法を用いることによ り極表面層の残留応力を簡便に計測することが可能であ る。なお，極表面層に存在する残留応力が材料の特性に与 える影響については，まだ報告されていない．

これまでに, キャビテーション気泡の崩壊衝撃力を活用 したキャビテーション・ショットレス・ピーニング CSP

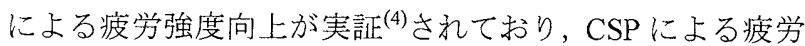
強度向上の主因は圧縮残留応力の導入であると考えられ ている.一方，円盤型砥石による研磨処理により引張残留 応力が生じることが知られている.

よって本報では, CSP や研磨処理などの表面処理によっ て生じた極表面層の残留応力を $2 \mathrm{D}$ 法により評価し, 残留 応力分布により制御することで, オーステナイト系ステン レス鋼 SUS316L の疲労強度に差異が生じることを平面曲 げ疲労試験により明らかにした。

\section{2. 実験装置および方法}

残留応力は, 2 次元 PSPC を用いた $2 \mathrm{D}$ 法で求めた。 図 1 には2D 法における座標を示す。本実験では， $\chi, \psi$ を21 通りに変えて 2 次元 PSPCによりデバイリングを計測し， 式(1)を満たすように残留応力を求めた。

$$
p_{1} \sigma_{x}+p_{2} \sigma_{y}+p_{3} \sigma_{z}+p_{4} \tau_{x y}+p_{5} \tau_{y z}+p_{6} \tau_{z x}=\ln \left(\frac{\sin \theta_{0}}{\sin \theta}\right)
$$

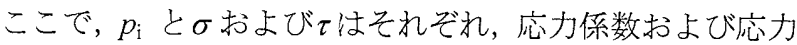
值であり， $\theta_{0}$ は無ひずみ状態での回折角である。

図 2 にはX 線の侵入深さを算出するための模式図を示 す. 入射前のX 線強度 $I_{1}$ と, 深さ $d$ まで侵入した際に材 料内部で減衰した X 線強度 $I_{(d)}$ の間には式(2)の関係がある。

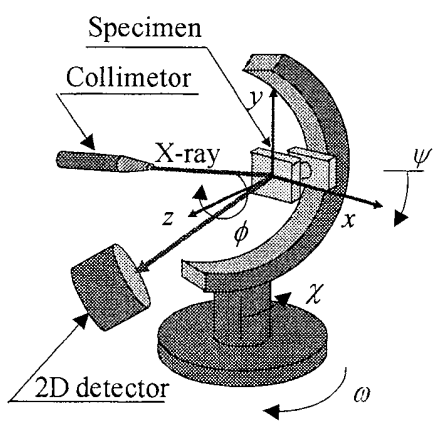

Fig. 1 Coordinate of $2 \mathrm{D}$ method

$$
\begin{aligned}
I_{(d)} & =I_{1}\left[1-\exp \left(-\mu \rho d\left(\frac{1}{\sin \omega}+\frac{1}{\sin (2 \theta-\omega)}\right)\right)\right] \\
d & =-\ln \left(1-\frac{I_{(d)}}{I_{1}}\right) \times\left(\mu(\lambda) \rho\left(\frac{1}{\sin \omega}+\frac{1}{\sin (2 \theta-\omega)}\right)\right)^{-1}
\end{aligned}
$$

ここで， $\mu, \rho$ はそれぞれ，材料の線吸収係数と密度であ る。したがって，侵入深さ $d$ は式(3)で表わされる，本報 では $I_{(d)} / I_{1}$ が 0.9 となる深さをX 線侵入深さとした。侵 入梁さ $d$ は入射角 $\omega$ ，回折角 $\theta$ で表すことができる。な お，回折面は $\gamma$ - $\mathrm{Fe} の 200$ 面の回折角 $2 \theta=80 \mathrm{deg}$ からの 回折 X 線を検出し計測を行った。

供試材には調質したオーステナイト系ステンレス鋼 SUS316L (JIS G 4305)を用いた。表面処理住研削加工およ びCNS (住友 3M), 円盤型砥石 (日本 RESIBON, 以下 Disc) による研磨処理を行った。また，Disc 仕上げを施した後に 伴水噴流水中キャビテーション噴流を用いた CSP 処理を 施した試験片を含め, 計 4 種類の平面曲げ疲労試験片を用 意した。CSP 処理は，高速水噴流のノズル直径 $2 \mathrm{~mm}$, 噴 射圧力 $30 \mathrm{MPa}$ ，低速水噴流のノズル $50 \mathrm{~mm}$, 噴射压力 0.02 $\mathrm{MPa}$ ，処理速度 $30 \mathrm{~mm} / \mathrm{min}$ で行った。生じた残留応力

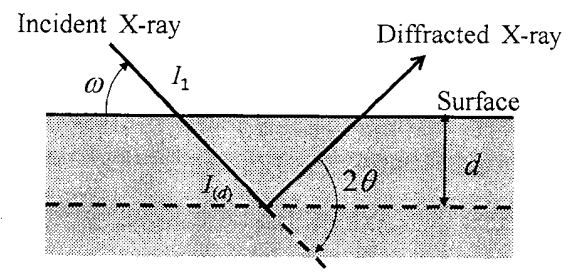

Fig. 2 X-ray path and absorption in a sample 


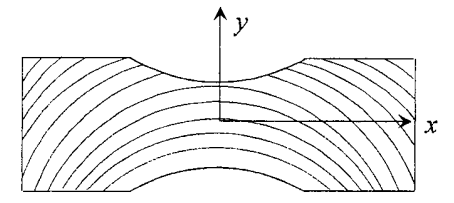

Fig. 3 Direction of coordinates on the specimen

は表面から 1 8 $4 \mathrm{~m}$ の深さにおいて $1 \mu \mathrm{m}$ ごとに $2 \mathrm{D}$ 法に より測定した. 計測の際の座標軸俚加工痕に対して用いて 図 3 のように定義した。なお，X線発生には Cr 管球を用 い, 特性 X 線は K $\alpha$ 線老使用し, 管電流, 管電圧は $40 \mathrm{~mA}$, $35 \mathrm{kV}$ とし。

\section{3. 実験結果および考察}

末処理試験片, 研削加工, CNS, Discによる研磨処理, および Disc 仕上げを施した後に CSP 処理を施した SUS316L 平面曲げ試験片長手方向の表面粗さを図 4 に, 極表面層に生じた残留応力の計測結果を図 5 に示す.極表 面層の残留応力計測に加え, 平面曲げ疲労試験を $10^{7}$ 回ま で行い，得られた $S-N$ 線図を図 6 に示寸。なお疲労強度の 推定には Littleの方法(5)を用いた。図 5 より，極表面層で の残留忘力は圧縮残留応力が大きい順に，未処理試験片， Disc + CSP 試験片，CNS 試験片，研削試験片，Disc 試験 片である。一方, 図 6 より, 疲労強度が大きい順に, CNS 試験片，Disc + CSP 試験片，研削試験片，未処理試験片， Disc 試験片となっている.さらに, 図 4 より, 表面粗さが 小さい順に, 未処理試験片, CNS 試験片, 研削試験片, Disc 試験片，Disc + CSP 試験片となっておう，疲労強度に 及ぼす表面粗さの影響㥛表面層の残留応力に比へ，極めて 小さいといえる.

図 5 および図 6 より, CNS 試験片では，深さ $3 \mu \mathrm{m}$ にお いて若干の引張残留态力が存在しているものの, 深さの增 加に伴い減少していき, 深さ $8 \mu \mathrm{m}$ では $700 \mathrm{MPa}$ を超える 圧縮残留応力が存在していることから, 深い位置での大き な圧縮残留忘力の働きが極表面層の若干の引張残留応力 の影響を補ったため，疲労強度が $408 \mathrm{MPa}$ と最も高くな ったと考えられる。また, 未処理試験片は極表面層に圧縮 残留応力が存在しているにも関わらず疲労強度が CNS 試 験片, 研削試験片, Disc + CSP 試験片に比べて小さいが, この要因としては, 調質材の粗大な結晶粒が機械加工によ り微細化したことが挙げられる。

研削試験片，Disc 試験片，およびDisc + CSP 試験片の

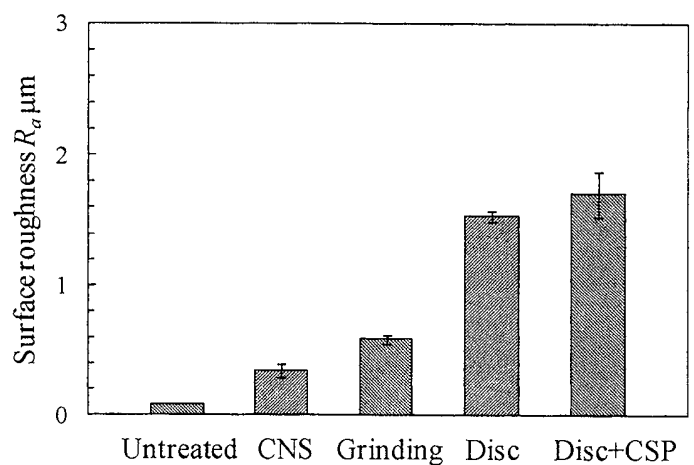

Fig. 4 Surface roughness of treated specimens

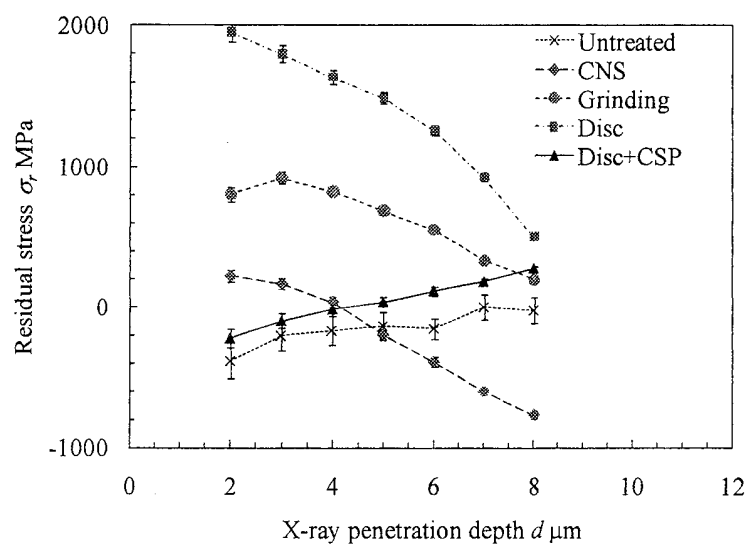

Fig. 5 Residual stress in sub-surface generated by surface treatment

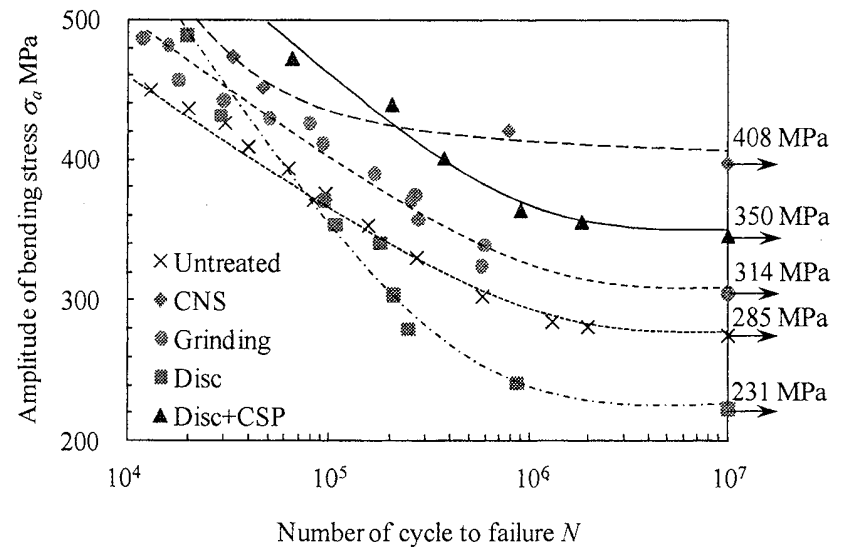

Fig. 6 Difference of fatigue strength by surface treatment

深さ $8 \mu \mathrm{m}$ における残留応力が同程度であるのに対し，疲 労強度に大きな差異が生じていることから,この大きな差 異の支配的な要因の一つに極表面層の残留応力を举げる ことができる．特に，Disc 試験片の極表面層には約 1900 $\mathrm{MPa}$ の著しく大きな引張残留応力が存在しており，加え て疲労強度が $231 \mathrm{MPa}$ であるのに対し，CSP 処理を行う だけで極表面層に約 $200 \mathrm{MPa}$ の圧縮残留応力を導入する ことができ, 疲労強度が約 $52 \%$ 増加し， $350 \mathrm{MPa}$ に向上 した.

\section{4. 結 言}

SUS316L に表面処理を施すと極表面層の残留忘力に大 きな差異が生じ，この差異が疲労強度に大きな影響を与え， 一般的には計測が困難な極表面層に圧縮残留応力を導入 することで疲労強度が飛躍的に向上した。

なお本研究の一部は日本学術振興会科学研究費補助金 [基盤研究(A) 20246030]によったことを記す.

\section{参考文献}

(1) 日本材料学会, X 線応力測定標準, JSMS-SD-5-02 (2002).

(2) B.B.He and K.L.Smith, Proc. 1998 SEM Spring Conf. Exp. Appl. Mech.,(1998), 217.

(3) 佐野ほ力 7 名, 日本材料学会 第 55 期学術講演会講演 論文集, (2006), 242.

(4) H. Soyama, et al., J. Mater. Sci., 43 (2008), 5028.

(5) R.E. Little, ASTM-STP-511 (1972), 29 